\title{
EXPERIMENTAL STUDY OF THE INFLUENCE OF THE DEGREE OF FILLING ON THE EFFECTIVE INDICATORS OF A ROTARY PISTON ENGINE
}

\section{ЕКСПЕРИМЕНТАЛЬНІ ДОСЛІДЖЕННЯ ВПЛИВУ СТУПЕНЯ НАПОВНЕННЯ НА ЕФЕКТИВНІ ПОКАЗНИКИ РОТОРНО-ПОРШНЕВОГО ДВИГУНА}

\author{
Oleksandr. S. Mytrofanov \\ mitrofanov.al.ser@gmail.com \\ ORCID: 0000-0003-3460-5369 \\ Arkadii Yu. Proskurin
arkadii.proskurin@nuos.edu.ua
ORCID: 0000-0002-5225-6767
}

О. С. Митрофанов,

канд. техн. наук, доцент

А. Ю. Проскурін,

канд. техн. наук, доцент

\author{
Admiral Makarov National University of Shipbuilding, Mykolaiv \\ Національний університет кораблебудування імені адмірала Макарова, м. Миколаїв
}

\begin{abstract}
Study of the influence of the degree of filling of the working cylinder on the energy and economic indicators of a rotary piston air engine.

Methods. The characteristics of the change in the performance indicators of a rotary piston air engine depending on the degree of filling are performed by the method of physical modeling, which, in the case of studying new samples of technical systems, is more accurate and reliable. The method of physical modeling made it possible to obtain the characteristics of work in real operating conditions, taking into account all the design features of the prototype of the air engine.

Results. The results of the experimental studies on the regulation of operating modes of the 12RPD-4,4/1,75 rotary piston air engine by changing the degree of filling are analyzed. Experimental dependences of changes in energy and economic indicators on the degree of filling of the working cylinder are presented. So, in the mode $P_{s}=0,7 \mathrm{MPa}$ and $n=1550 \mathrm{rpm}$, an increase in the degree of filling by 2,4 times makes it possible to increase the effective power of the rotary piston air engine by 1,9 times, and in the mode $P_{s}=0,5 \mathrm{MPa}$ and $n=1200 \mathrm{rpm}$ an increase in $\varepsilon_{1}$ by 2 times increases $\mathrm{Ne}$ by 1,5 . According to the regulation, $\varepsilon_{1}$ is an effective way to change the load mode of the air engine.

It has been determined that in all operating modes at fixed values of the rotary piston air engine speed, the degree of filling of the working cylinder also affects the change in the effective consumption of compressed air. So, in the mode $P_{s}=0,7 \mathrm{MPa}$ and $n=1550 \mathrm{rpm}$, an increase in the degree of filling by 2,4 times leads to an increase in the specific effective consumption of compressed air by 1,12 times, and in the mode $P_{s}=0,5 \mathrm{MPa}$ and $n=1200 \mathrm{rpm}$, an increase in $\varepsilon_{1}$ by a factor of 2 increases $g_{e}$ by 1,11 .

It has been experimentally proved that an increase in the degree of filling contributes to an increase in the resistance of the exhaust system of a rotary piston air engine. Under the conditions of the experiment, the value of the exhaust system resistance, for the entire range of $\varepsilon_{1}$ variation, did not exceed $0,075 \mathrm{MPa}$ and is a fairly low indicator.

Scientific novelty. On the basis of the carried out experimental studies of a prototype of a rotary piston air engine, the efficiency of regulation of operating conditions by changing the degree of filling of the working cylinder was evaluated. Practical importance. Recommendations were obtained for regulating the operating conditions of the prototype of the 12RPD-4,4/1,75 rotary piston air engine by changing the degree of filling of the working cylinder. This will make it possible to provide the specified power during the operation of the air engine with minimal consumption of compressed air.
\end{abstract}

Key words: compressed air; rotary piston air engine; experimental stand; effective indicators; degree of filling; movement mechanism.

Анотація. Метою статті є дослідження впливу ступеня наповнення робочого циліндра на енергетичні та економічні показники роторно-поршневого пневмодвигуна.

Методика. Характеристики зміни показників роботи роторно-поршневого пневмодвигуна від ступеня наповнення виконано методом фізичного моделювання, який у випадку дослідження нових зразків технічних систем $\epsilon$ більш точним і достовірним. Метод фізичного моделювання дозволив отримати характеристики роботи в реальних умовах експлуатації з урахуванням усіх конструктивних особливостей дослідного зразка пневмодвигуна. 
Результати. Проаналізовано результати експериментальних досліджень із регулювання режимів експлуатації роторно-поршневого пневмодвигуна 12РПД-4,4/1,75 за рахунок зміни ступеня наповнення. Наведено експериментальні залежності зміни енергетичних та економічних показників від ступеня наповнення робочого циліндра. Так, на режимі $P_{s}=0,7$ МПа та $n=1550$ об/хв збільшення ступеня наповнення у 2,4 рази дозволяє підвищити ефективну потужність роторно-поршневого пневмодвигуна у 1,9 разів, а на режимі $P_{s}=0,5 \mathrm{MПа} \mathrm{і}$ $n=1200$ об/хв збільшення $\varepsilon_{1}$ удвічі підвищує $N_{e}$ у 1,5 рази. Тому регулювання $\varepsilon_{1} \epsilon$ ефективним способом зміни режиму навантаження пневмодвигуна.

Визначено, що на всіх експлуатаційних режимах при фіксованих значеннях обертів роторно-поршневого пневмодвигуна ступінь наповнення робочого циліндра також впливає на зміну ефективної витрати стиснутого повітря. Так, на режимі $P_{s}=0,7$ МПа та $n=1550$ об/хв збільшення ступеня наповнення у 2,4 рази призводить до зростання питомої ефективної витрати стиснутого повітря у 1,12 рази, а на режимі $P_{s}=0,5$ МПа і $n=1200$ об/хв збільшення $\varepsilon 1$ удвічі збільшує $g_{e}$ у 1,11 разів.

Експериментально встановлено, що збільшення ступеня наповнення сприяє підвищенню опору випускної системи роторно-поршневого пневмодвигуна. В умовах проведення експерименту значення опору випускної системи для всього діапазону зміни $\varepsilon_{1}$ не перевищувало 0,075 МПа та було досить низьким показником.

Наукова новизна. На базі проведених експериментальних досліджень дослідного зразка роторно-поршневого пневмодвигуна виконано оцінку ефективності регулювання експлуатаційних режимів шляхом зміни ступеня наповнення робочого циліндра.

Практична значимість. Отримані рекомендації щодо регулювання експлуатаційних режимів дослідного зразка роторно-поршневого пневмодвигуна 12РПД-4,4/1,75 шляхом зміни ступеня наповнення робочого циліндра. Це дозволить у процесі експлуатації пневмодвигуна забезпечувати задану потужність за мінімальних витрат стиснутого повітря.

Ключові слова: стиснуте повітря; роторно-поршневий пневмодвигун; експериментальний стенд; ефективні показники; ступінь наповнення; механізм руху.

\section{FORMULATION OF THE PROBLEM}

Gas distribution mechanism has a significant effect on the efficiency of converting the energy of a compressed working fluid into an air engine. The design of gas distribution mechanism through such parameters as the relative dead volume $\varepsilon_{0}$, the degree of filling $\varepsilon_{1}$ and the compression ratio $\varepsilon_{5}$ directly affects the working process of the air engine and, accordingly, the type of indicator diagram [1]. The main gas distribution designs for piston expansion machines are spool, valve and mixed ones. Each method of gas exchange has a number of advantages and disadvantages. So, the spool gas distribution mechanism can be attributed to the simplest ones.

It has the simplest and most reliable design, provides the minimum weight and dimensions of the engine. However, with this method of gas exchange, the relative dead volume can reach sufficiently high values, which undoubtedly leads to a decrease in engine efficiency $[1 ; 2]$. The use of a valve mechanism can significantly reduce the value of the relative dead volume, however, it somewhat complicates the engine design. In turn, air engines with a valve mechanism are divided according to the valve drive method. The most effective and at the same time most complex is the hydraulic (or air) valve drive with electronic control of gas distribution. Such a design of gas distribution mechanism makes it possible to ensure effective regulation of the engine operating modes by changing the degree of filling (usually, the operating modes are regulated by changing the pressure of the working fluid at the inlet to the air engine).
The 12RPD-4,4/1,75 rotary piston air engine developed by the machine-building enterprise MotorPlus LLC is one of the prototypes, which has a number of design differences from many known air engines [3]. One of the design differences of the air engine is the gas distribution mechanism, which is quite simple and at the same time provides the ability to adjust gas distribution. In accordance with this, the rotary piston air engine has its own characteristics in the organization of the working process and requires a number of research tests to determine its efficiency of energy conversion.

\section{ANALYSIS OF RECENT RESEARCH AND PUBLICATIONS}

The optimal organization of the gas exchange process can significantly increase the efficiency of the air engine; therefore, a large number of researchers pay a lot of attention to this issue.

For each gas distribution mechanism and operating parameters, there are recommendations for gas distribution, as well as the geometric dimensions of the gas exchange parts. So, for example in [4] the results of calculating the spool air distributor are presented, and the issue of the optimal dimensions of the compressed air inlet ports is considered. In work [5] experimental studies of various operating modes of a piston air engine are presented at fixed values, optimally selected, of the gas exchange phases. Recommendations regarding the necessary gas distribution phases of piston air engines, as well as the results of their experimental tests, are given in $[6 ; 7]$.

In terms of their parameters, serial air engines do not always meet the necessary needs of some specific areas 
of application. For example, for transport plants, air engines converted from conventional four-stroke gasoline engines are used. The basic of the main tasks in the conversion is precisely the re-equipment of the gas distribution mechanism. In works [8-10], the issue of constructive re-equipment of the gas distribution mechanism is considered, and the results of experimental studies of such convertible air engines are presented. The issue of converting engines and the methodology for organizing the workflow into an air engine are discussed in detail in $[11 ; 12]$. In addition, it is worth noting the significant contribution to the experimental and theoretical study of the air engine of domestic scientists, such as F.I. Abramchuk, A.I. Voronkov, V.A. Bogomolov, A.M. Turenko, A.I. Kharchenko, I.M. Nikitchenko, S.S. Zhilin and others.

\section{SEPARATION OF PREVIOUSLY UNSOLVED PARTS OF THE OVERALL PROBLEM}

Mostly converted or serial air engines do not have the ability to adjust the gas distribution depending on the operating mode. The design of these air engines provides an average optimum fixed value of gas distribution, which is unchanged during the operation of the air engine. Thus, in valve distribution, the valves are driven by a camshaft with profiled cams, which, in turn are driven by a rigid connection to the crankshaft. Accordingly, it is practically impossible to provide variable gas distribution phases in such a design. To provide an independent valve drive, for example, hydraulic or air, it is necessary to significantly complicate the design of the air engine and implement electronic control.

The 12RPD-4,4/1,75 rotary piston air engine of a new design is a prototype with motion and gas distribution mechanisms different from the existing air engines. That is why there are no experimental data for it on the change in effective performance indicators, depending on the gas distribution phases adjustment. Accordingly, the experimental studies and their analysis are necessary and justified.

\section{THE AIM OF THE RESEARCH}

The aim of the research is to study the influence of regulating the degree of filling of the working cylinder on the effective indicators of a rotary piston air engine.

\section{METHODS, OBJECT AND SUBJECT OF THE RESEARCH}

The main research methods for new types of equipment are mathematical and physical modeling. These methods allow you to get the main characteristics of the work and evaluate the efficiency of energy conversion. From an economic point of view, mathematical modeling is a cheaper method (does not require large material costs), but it should be noted that the accuracy and range of application of the mathematical model depends on the assumptions made and correct input data. In the case of studying a new sample of a technical system, which is a rotary piston air engine, the method of physical modeling is more accurate and reliable, and mathematical modeling can be used only for a preliminary assessment of the parameters of the air engine operation.

The use of physical modeling will make it possible to determine the characteristics of work in real operating conditions, taking into account all the design features of the air engine. Physical modeling is indispensable for formulating practical recommendations for the operation and maintenance of a new air engine, can also be used to supplement and improve the mathematical model.

The object of the research is the prototype of the 12RPD-4,4/1,75 rotary piston air engine and the processes of converting the energy of compressed air in it with variable gas distribution phases. The subject of the research is the dependences of changes in the main effective indicators of the air engine operation.

\section{THE MAIN MATERIAL}

Experimental studies of the influence of the gas exchange phase regulation on the efficiency of energy conversion of compressed air energy were carried out on the basis of the 12RPD-4,4/1,75 12-cylinder rotary piston air engine with a working volume of $320,6 \mathrm{~cm}^{3}$ (Fig. 1). The air engine is the part of an experimental stand created at the machine-building enterprise Motor-Plus LLC with the participation of the Advanced Energy Technologies Center of the Admiral Makarov National University of Shipbuilding [13]. Experimental studies of the prototype were carried out without preheating the air in front of the inlet receiver, and the regulation was carried out by turning the control camshaft [3].

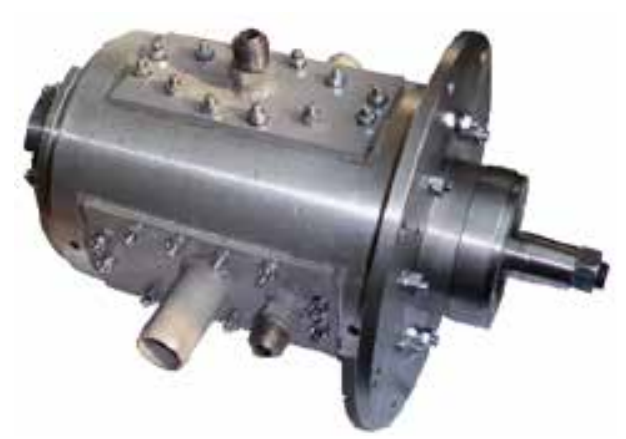

Fig. 1. The prototype of the $12 \mathrm{RPD}-4,4 / 1,75$ rotary piston air engine

The gas distribution mechanism of the air engine allows you to change the duration of the main processes of the working cycle of the rotary piston air engine (Fig. 2), namely the duration of the filling process of the working cylinder (section 1-2) and reverse compression (section 5-6).

These processes of the working cycle correspond to the corresponding volumes, namely the volume 


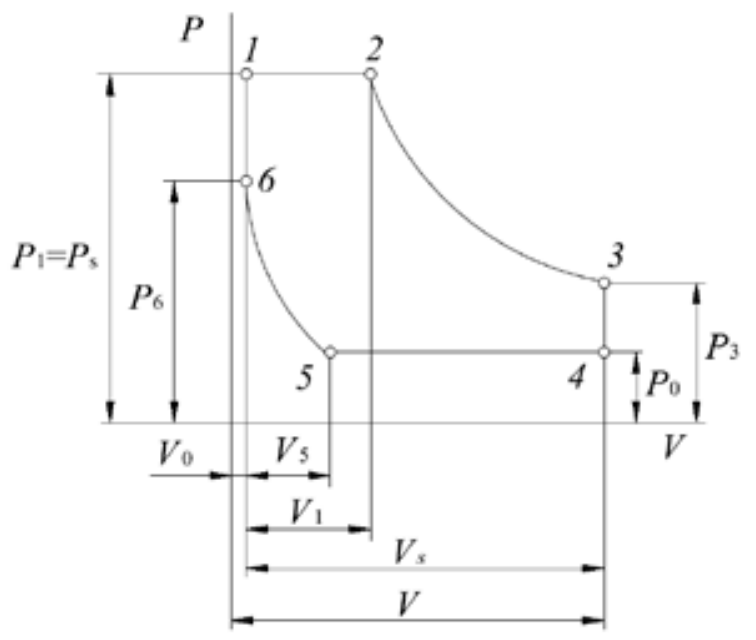

Fig. 2. General view of the theoretical indicator diagram of a rotary piston air engine in $P-V$-coordinates

of filling $V_{1}$ and the volume of reverse compression $V_{5}$, which are reflected in the theoretical indicator diagram in Fig. 2. Dividing these volumes by the working volume $V_{s}$ of the rotary piston air engine, we obtain dimensionless adjusting parameters of the working cycle: such as the filling ratio $\varepsilon_{1}=V_{1} / V_{s}$ and the reverse compression ratio $\varepsilon_{5}=\left(V_{5}\right) /\left(V_{s}\right)$.

Fig. 3 shows the experimental dependences of changes in effective power $N_{e}$, average effective pressure $P_{e}$ and torque $M_{k}$ of a rotary piston air engine in accordance with changes in the degree of filling. The presented dependences correspond to two operating conditions, which differ in pressure $P_{s}$ in the inlet receiver and engine speed $n$. In the first case, the working pressure in the air engine inlet receiver was $0,7 \mathrm{MPa}$ and the speed was $1550 \mathrm{rpm}$, and in the second case, $P_{s}=0,5 \mathrm{MPa}$ and $n=1200 \mathrm{rpm}$.

According to the results obtained in the test mode $P_{s}=0,7 \mathrm{MPa}$ with an increase in the degree of filling by 2,4 times, the effective power of the rotary piston air engine increases by 1,9 times, and in the mode $P_{s}=$ $0,5 \mathrm{MPa}$ with an increase in $\varepsilon_{1}$ by 2 times $N_{e}$ increases by 1,5 times. This is due to the fact that with an increase in the degree of filling, the area of the indicator diagram increases due to an increase in the duration of the filling process (see Section 1-2 in Fig. 2), as well as the fact that the expansion process (see Section 2-3 in Fig. 2)
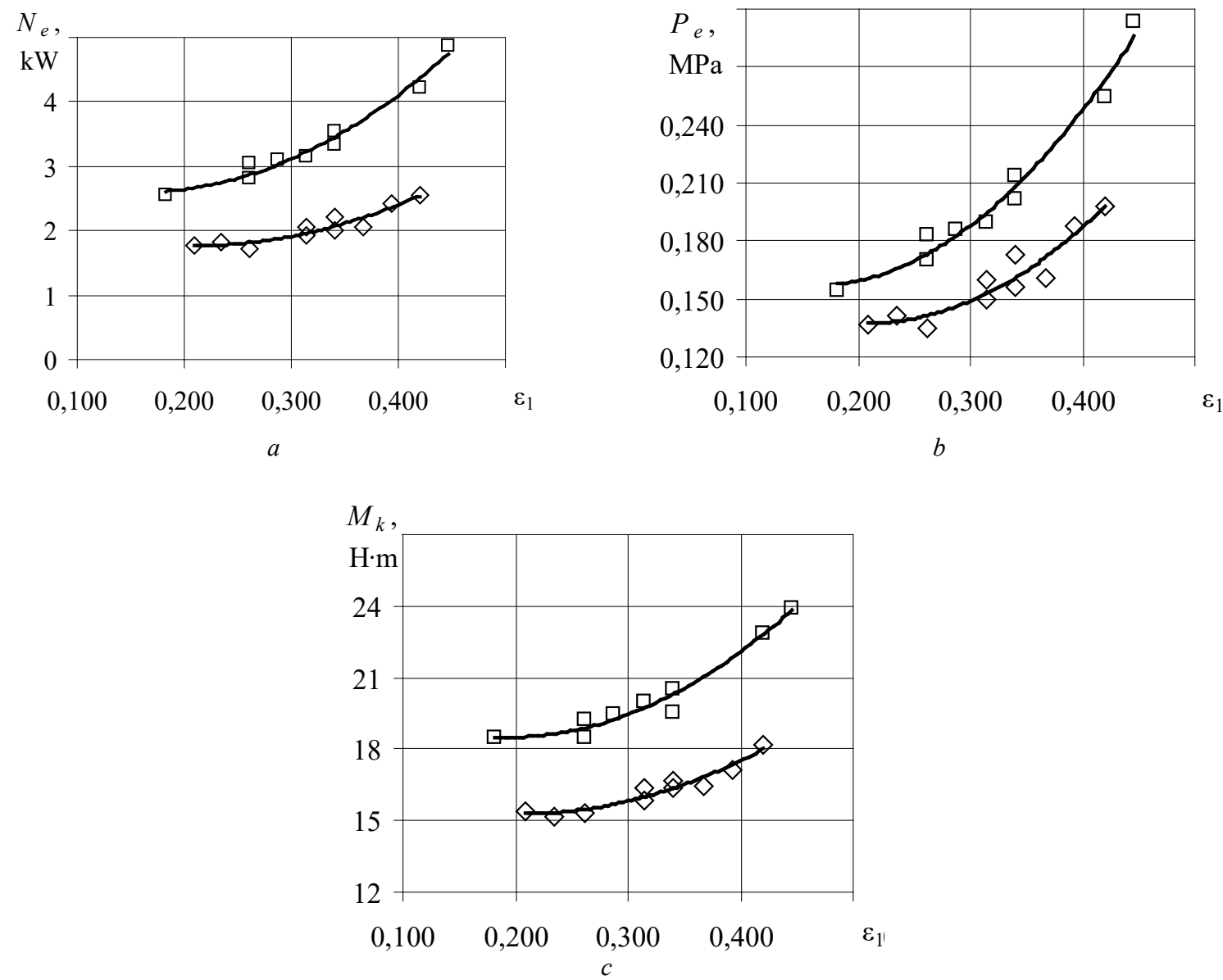

Fig. 3. Change in the effective parameters of a rotary piston air engine from the degree of filling: $a$ - effective power; $b-$ average effective pressure; $c$ - torque $\square-P_{s}=0,7 \mathrm{MPa}, n=1550 \mathrm{rpm} ; \diamond-P_{s}=0,5 \mathrm{MPa}, n=1200 \mathrm{rpm}$ 


\section{ЕНЕРГЕТИЧНЕ МАШИНОБУДУВАННЯ № 4- 2020}

occurs at high pressures in the working cylinder. Thus, at fixed rpm values, by changing the degree of filling, it is possible to provide effective regulation of the power of the rotary piston air engine.

In addition to energy indicators, the degree of filling has a significant impact on the economic indicators of the air engine. So, Fig. 4 shows the experimental dependences of the change in the hourly consumption of compressed air $G_{a i r}$ and the specific effective consumption $g_{e}$ depending on the degree of filling for various operating modes. According to the presented results of experimental studies, with a decrease in the value of the degree of filling, the effective consumption of compressed air decreases. For the test mode $P_{s}=0,7 \mathrm{MPa}$, with a decrease in the degree of filling by $59 \%$, the specific effective consumption of compressed air decreases by $11 \%$, in the test mode $P_{s}=0,5 \mathrm{MPa}$, with a decrease in $\varepsilon_{1}$ by $50 \%, g_{e}$ decreases by $10 \%$.

In addition, according to the above experimental data, a fairly effective way to regulate the load of a rotary piston air engine is to change the compressed air pressure in the inlet receiver, which can be achieved by reducing the compressed air using a gas reducer. The use of both control methods at the same time will allow ensuring the minimum values of the hourly consumption of compressed air at the required power over the entire range of changes in the load of the rotary piston air engine.

With an increase in the degree of filling, the expansion process ends at high pressures in the working cylinder, which accordingly contributes to an increase in the value of the exhaust air pressure in the outlet receiver of the rotary piston air engine (Fig. 5).

According to the results obtained in the test mode $P_{s}=0,7 \mathrm{MPa}$, with an increase in the degree of filling by 2,4 times, the resistance of the exhaust system of the air engine increases by 2,1 times, and in the mode $P_{s}=0,5 \mathrm{MPa}$, with an increase in $\varepsilon_{1}$ by 2 times, the resistance increases by 1,5 times. An increase in the resistance of the exhaust system of the air engine

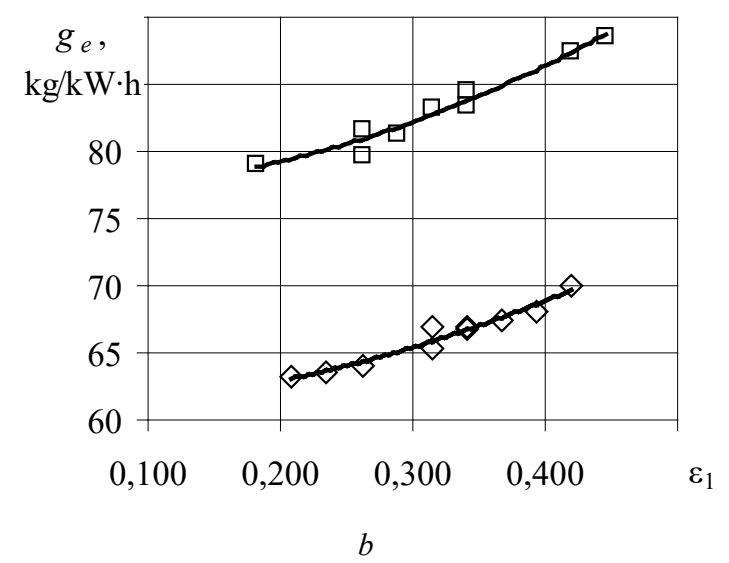

Fig. 4. Dependences of the change in the consumption of compressed air at different values of the degree of filling: $a$ - hourly consumption of compressed air; $b$ - specific effective consumption of compressed air $\square-P_{s}=0,7 \mathrm{MPa}, n=1550 \mathrm{rpm} ; \diamond-P_{s}=0,5 \mathrm{MPa}, n=1200 \mathrm{rpm}$

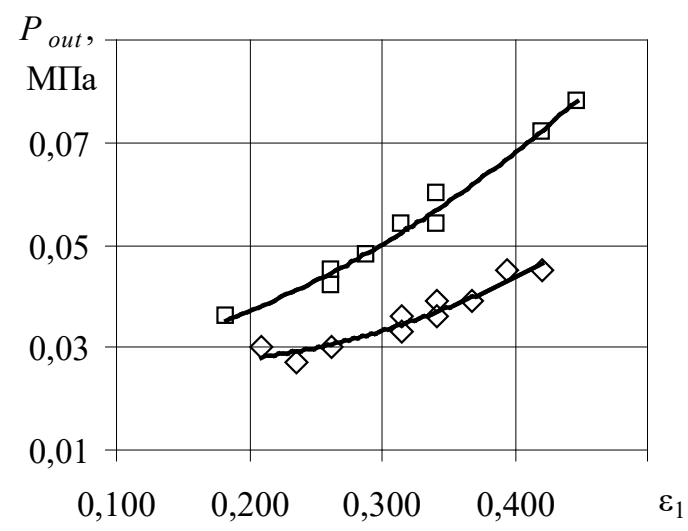

Fig. 5. Change in the pressure of the exhaust air in the outlet receiver of a rotary piston air engine, depending on the degree of filling of the working cylinder for various operating modes

$\square-P_{s}=0,7 \mathrm{MPa}, n=1550 \mathrm{rpm} ; \diamond-P_{s}=0,5 \mathrm{MPa}, n=1200 \mathrm{rpm}$ 
has a negative effect on economic indicators, expressed in an increase in the specific effective consumption of compressed air. The resistance value of the exhaust system of the air engine with the installed silencer in accordance with the recommendations $[1 ; 14]$ should not exceed the value of 0,12 MPa. So, under the conditions of experimental studies on the entire range of variation of the degree of filling, the resistance value of the exhaust system of a rotary piston air engine did not exceed 0,075 MPa.

\section{DISCUSSION OF THE OBTAINED RESULTS}

Experimental studies of a rotary piston air engine have confirmed the effectiveness of regulation of operating modes by changing the degree of filling of the working cylinder. The analysis of the research results showed that this method is effective and efficient regardless of the value of such important operational parameters as the pressure in the inlet receiver (working pressure) and the speed of the air engine.

Increasing the filling ratio increases the average effective pressure and the effective power of the air engine. However, with an increase in the energy performance of the air engine, an increase in the degree of filling simultaneously worsens the economic performance and leads to an increase in the resistance of the exhaust system. Together with the degree of filling, the pressure in the inlet receiver affects the energy and economic performance of the rotary piston air engine. Accordingly, to obtain the most optimal ratio of the given power and the efficiency of the air engine, it is necessary to regulate both of these parameters. To determine the ratio of $P_{s}$ and $\varepsilon_{1}$, at which the optimal ratio of energy and economic indicators of the air engine for various operating modes is ensured, it is necessary to conduct a series of additional experimental studies.
Separate experimental studies are required for the issue of changing the minimum cycle temperature when regulating operating modes by changing the degree of filling and operating pressure. So, according to $[1 ; 15]$, an increase in the value of $P_{s}$ and $\varepsilon_{1}$ contributes to a decrease in the minimum temperature of the exhaust air at the outlet from the air engine. Accordingly, to ensure efficient and trouble-free operation of the air engine, the value of this temperature should not be lower than the permissible value. In addition, experimental research is required to study the question of the influence of preheating of compressed air before expansion on the regulation of operating modes.

\section{CONCLUSIONS}

1. The operational characteristics of changes in the energy and economic parameters of the 12RPD-4,4/1,75 rotary piston air engine are obtained and analyzed when adjusting the degree of filling of the working cylinder.

2. It is defined that at fixed rpm values, an effective way to regulate a rotary piston air engine is to change the degree of filling and operating pressure, and it is also determined that these parameters have a significant effect on the specific effective consumption of compressed air at all operating modes. For example, an increase in $\varepsilon_{1}$ by 2,4 times at $n=1550 \mathrm{rpm}$ and $P_{s}=0,7 \mathrm{MPa}$ increases $N_{e}$ by 1,9 times, while ge grows only by 1,12 times.

3. It was found that with an increase in the degree of filling and the value of the working pressure, the resistance of the exhaust system of the rotary piston air engine increases. According to the experimental data obtained, the resistance value of the exhaust system of the rotary piston air engine for the entire range of variation of the degree of filling did not exceed 0,075 MPa, which is a significantly lower indicator of the permissible value of such exhaust systems with a silencer.

\section{REFERENCES}

[1] Turenko A.N., Bogomolov V.A., Abramchuk F.I., Kharchenko A.I., Shilov A.I. (2008). O vybore parametrov porshnevogo pnevmodvigatelya. rabotayushchego $\mathrm{v}$ sostave gibridnoy energoustanovki avtomobilya [On the selection of parameters of a piston air motor operating as part of a hybrid power plant of a car]. Avtomobilnyy transport [Automobile transport], 22. P. 7-13.

[2] Zelenetskiy S.B., Ryabkov Ye.D., Mikerov A.G. (1976). Rotatsionnyye pnevmaticheskiye dvigateli [Rotary pneumatic engines]. Leningrad : Mashinostroyeniye [Mechanical Engineering].

[3] Mytrofanov O.S., Shabalin Yu.V., Biryuk T.F., Yefenina L.O. (2019). Pat. na vynakhid Ukrayiny № 120489. Porshneva mashyna; zayavl. № a201902189 10.09.2019; opubl. 10.12.2019, byul. № 23 [Patent for the invention of Ukraine № 120489. The piston machine; claimed № a201902189 on September 10, 2019; publ. December 10, 2019, bul. № 23].

[4] Voronkov O.I., Lisina O.Yu., Nikitchenko I.N. (2014). Vyznachennia chasu peretynu v zolotnykovomu rozpodilnyku pnevmodvyhuna [Determination of the time of crossing in the spool distributor of a pneumatic engine]. Avtomobilnyy transport: sbornik nauch. trudov KHNADU [Road transport: Collection of Scientific Publications of KNAHU], 34. P. 39-43.

[5] Kunt Akif M. (2016). Transformation of a Piston Engine into a Compressed Air Engine with Rotary Valve. SSRG International Journal of Mechanical Engineering (SSRG-IJME). Vol. 3, № 11. P. 1-5. doi: 10.14445/23488360/IJME-V3I11P101

[6] Venkatesh Boddapati, Vinod S.V.V., Babu M. Dora (2015). Air Powered Vehicle - an Eco Friendly Engine. International Journal of IT, Engineering and Applied Sciences Research (IJIEASR), January. Vol. 4, № 1. P. 29-33.

[7] Shubham Kumar, Pankaj Pradhan, Khan Kumar, Hussain Zakeer, Anil B. Kumar, Chaithanya M. (2017). Design and Developing of Compressed Air Engine. International Research Journal of Engineering and Technology (IRJET). Vol. 4, № 05. P. 1468-1474. 
[8] Arjit Mourya, Arif Khan, Darshika Bajpayee, Nainsi Gupta (2014). Modified Compressed Air Engine Two Stroke Engine Working On The Design Of A Four Stroke Petrol Engine. International Journal On Theoretical And Applied Research In Mechanical Engineering, № 3(4). P. 58-60.

[9] Allam S., Zakaria M. (2018). Experimental Investigation of Compressed Air engine Performance. International Journal of Engineering Inventions, February. Vol. 7, № 1, Ver. II. P. 13-20.

[10] Qihui Yu, Maolin Cai (2015). Experimental Analysis of a Compressed Air Engine. Journal of Flow Control, Measurement \& Visualization, № 3. P. 144-153. http://dx.doi.org/10.4236/jfcmv.2015.34014

[11] Voronkov A.I., Nikitchenko I.N. (2015). Rabochiy protsess avtomobilnogo pnevmodvigatelya : monografiya [Working process of an automative pneumatic engine : monograph]. Kharkov : KNAHU Publ.

[12] Voronkov O.I. (2017). Metodolohiia orhanizatsii robochoho protsesu pnevmodvyhuna kombinovanoi enerhetychnoi ustanovky miskoho avtomobilia, Dokt., Diss. [Methodology of organization for the working process of a pneumatic engine of combined power plant for a city car. Doct. Diss.]. Kharkiv.

[13] Mytrofanov O.S. (2019). Stend dlya vyprobuvannya ta doslidzhennya rotorno-porshnevykh dvyhuniv [Stand for testing and research of rotary-piston engines]. Zbirnyk naukovykh prats' Natsional'noho universytetu korablebuduvannya imeni admirala Makarova [Proceedings of the Admiral Makarov National University of Shipbuilding], № 1(475). P. 51-57.

[14] Borisenko K.S. (1958). Pnevmaticheskiye dvigateli gornykh mashin [Pneumatic motors of mining machines]. Moscow : Ugletekhizdat.

[15] Degtyarev V.I., Myalkovskiy V.I., Borisenko K.S. (1979). Shakhtnyye pnevmomotory [Mine pneumatic motors]. Moscow : Nedra, 1979.

\section{BIBLIOGRAPHY}

[1] Туренко А.Н., Богомолов В.А., Абрамчук Ф.И., Харченко А.И., Шилов А.И. О выборе параметров поршневого пневмодвигателя, работающего в составе гибридной энергоустановки автомобиля. Автомобильный трансnорт. 2008. Вып. 22. С. 7-13.

[2] З Зеленецкий С.Б., Рябков Е.Д., Микеров А.Г. Ротационные пневматические двигатели. Л. : Машиностроение, 1976.

[3] Митрофанов О.С., Шабалін Ю.В., Бірюк Т.Ф., Єфеніна Л.О. Пат. на винахід України № 120489. Поршнева; заявл. № a201902189 10.09.2019; опубл. 10.12.2019, бюл. № 23.

[4] Воронков О.І., Лісіна О.Ю., Нікітченко І.М. Визначення часу перетину в золотниковому розподільнику пневмодвигуна. Автомобильный транспорт : сб. науч. тр. ХНАДУ. 2014. Вып. 34. С. 39-43.

[5] Kunt Akif M. Transformation of a Piston Engine into a Compressed Air Engine with Rotary Valve. SSRG International Journal of Mechanical Engineering (SSRG-IJME). November, 2016. Vol. 3, № 11. P. 1-5.

[6] Venkatesh Boddapati S.V.V., Vinod M., Babu Dora. Air Powered Vehicle - an Eco Friendly Engine. International Journal of IT, Engineering and Applied Sciences Research (IJIEASR). January, 2015. Vol. 4, № 1. P. 29-33.

[7] Shubham Kumar, Pankaj Pradhan, Khan Kumar, Hussain Zakeer, Anil B. Kumar, Chaithanya M. Design and Developing of Compressed Air Engine. International Research Journal of Engineering and Technology (IRJET). 2017. Vol. 4, № 05. P. $1468-1474$.

[8] Arjit Mourya, Arif Khan, Darshika Bajpayee, Nainsi Gupta. Modified Compressed Air Engine Two Stroke Engine Working On The Design Of A Four Stroke Petrol Engine. International Journal On Theoretical And Applied Research In Mechanical Engineering. 2014. № 3(4). P. 58-60.

[9] Allam S., Zakaria M. Experimental Investigation of Compressed Air engine Performance. International Journal of Engineering Inventions. February, 2018. Volume 7, № 1, Ver. II. P. 13-20.

[10] Qihui Yu, Maolin Cai. Experimental Analysis of a Compressed Air Engine. Journal of Flow Control, Measurement \& Visualization. 2015. № 3. P. 144-153.

[11] Воронков А.И., Никитченко И.Н. Рабочий процесс автомобильного пневмодвигателя : монография. Харьков : ХНАДУ, 2015.

[12] Воронков О.І. Методологія організації робочого процесу пневмодвигуна комбінованої енергетичної установки міського автомобіля : дис. д-ра техн. наук: 05.05.03. Харків, 2017.

[13] Митрофанов О.С. Стенд для випробування та дослідження роторно-поршневих двигунів. Збірник наукових праць Начіонального університету кораблебудування імені адмірала Макарова. 2019. № 1(475). С. 51-57.

[14] Борисенко К.С. Пневматические двигатели горных машин. М. : Углетехиздат, 1958.

[15] Дегтярев В.И., Мялковский В.И., Борисенко К.С. Шахтные пневмомоторы. М. : Недра, 1979.

(C) О. С. Митрофанов, А. Ю. Проскурін Дата надходження статті до редакції: 27.11.2020 Дата затвердження статті до друку: 14.12.2020 